\title{
Analisis Konten pada Buku Teks Bahasa Inggris untuk Kelas X Berjudul Bahasa Inggris untuk SMA/MA/SMK/MAK Kelas X
}

\author{
Content Analysis on English Textbooks for Class X Title \\ English for High School
}

\author{
Mela Meliawati*, dan Fuad Abdul Hamied \\ Universitas Pendidikan Indonesia, Bandung, Jawa Barat, Indonesia \\ kireinamela@gmail.com*, fuadah@upi.edu
}

Naskah diterima tanggal 07/11/2019, direvisi akhir tanggal 02/03/2020, disetujui tanggal 24/04/2020

\begin{abstract}
Abstrak
Buku teks berfungsi sebagai salah satu bahan ajar yang bermanfaat dalam kurikulum. Tujuan penelitian untuk mengetahui bahwa buku teks bahasa Inggris untuk SMA/MA/SMK/MAK kelas X memenuhi kriteria evaluasi buku teks menurut para ahli yaitu Cunningsworth (1995), Harmer (2007) dan Badan Standar Nasional Pendidikan. Data dikumpulkan dengan cara merancang kriteria evaluasi buku teks yang berisi kriteria standar untuk mengevaluasi buku teks bahasa Inggris dan menjelaskan relevansi buku teks dengan materi kurikulum bahasa Inggris 2013. Peneliti menemukan bahwa buku teks yang dianalisis memenuhi $66.7 \%$ dalam kriteria English as a Foreign Language (EFL). Ada delapan kriteria evaluasi buku teks menurut Cunningsworth dan Harmer, yaitu (1) tujuan dan pendekatan, (2) desain dan organisasi, (3) konten bahasa, (4) skil, (5) topik, (6) metodologi, (7) pertimbangan praktis, dan (8) instruksi. Kemudian, 33.3\% buku teks ini tidak memenuhi kriteria buku teks EFL yang baik. Selain itu, berdasarkan hasil penelitian dan analisis penelitian, dapat menyimpulkan bahwa buku teks ini dikategorikan "baik" dengan mencapai skor rata-rata 90\% dari ketujuh kriteria yang ditentukan oleh Badan Standar Nasional Pendidikan. Ketujuh kriteria dapat diklasifikasikan "baik" berdasarkan kesesuaian materi dengan standar kompetensi dan kompetensi dasar (83.3\%), akurasi materi (83.3\%), bahan pendukung pembelajaran (90\%), ketepatan bahasa (100\%), teknik presentasi $(100 \%)$, teknik belajar mengajar $(100 \%)$, dan cakupan presentasi (81.8\%). Dan juga buku teks bahasa Inggris yang dianalisis relatif relevan dengan kurikulum 2013. Oleh karena itu, diharapkan bahwa guru dapat melengkapi beberapa kekurangan tersebut dengan materi lain untuk mencapai tujuan yang ditargetkan dalam kurikulum 2013.
\end{abstract}

Kata kunci: analisis konten, buku teks EFL, evaluasi buku teks

\begin{abstract}
The textbook serves as one of the useful teaching materials in the curriculum. The purpose of the study was to find out that English textbooks for grade X/SMA / MA / SMK / MAK meet the textbook evaluation criteria according to experts, namely Cunningsworth (1995), Harmer (2007) and the National Education Standards Board. Data was collected by designing textbook evaluation criteria that contained standard criteria for evaluating English textbooks and explaining the relevance of books to the 2013 English curriculum material. Researchers found that the manuals analyzed fulfilled $66.7 \%$ of the requirements for English as a Foreign Language (EFL). There are eight criteria for evaluating textbooks according to Cunningsworth and Harmer, namely (1) objectives and approaches, (2) design and organization, (3) language content, (4) skills, (5) topics, (6) methodology, (7) practical considerations, and (8) instructions. Then, 33.3\% of these textbooks did not meet the criteria of good EFL textbooks. Also, based on the results of research and research analysis, it can be concluded that this textbook is categorized as "good" by achieving an average score of $90 \%$ of the seven criteria determined by the National Education Standards Board. The seven criteria can be classified as "good" based on the suitability of the material with
\end{abstract}


competency standards and essential competencies (83.3\%), material accuracy (83.3\%), learning support materials (90\%), language accuracy (100\%), presentation techniques (100\%), teaching and learning techniques (100\%), and coverage of presentations (81.8\%). And also, English textbooks that were analyzed relative relevant to the curriculum of 2013. Therefore, it is expected that teachers can complete some of the shortfalls with other materials to achieve the objectives targeted in the curriculum of 2013.

Keywords: content analysis, EFL textbooks, textbook evaluations

\section{PENDAHULUAN}

Buku teks adalah salah satu input pendidikan yang paling penting (Altbach et.al., 1991; Tomlinson., 2001; Garinger., 2001; Richards., 2001; Lee., 2003). Buku teks memberi guru masukan yang berharga, seperti materi, latihan, instruksi, dan teks untuk tujuan pendidikan. Selain itu, buku teks juga menyediakan kerangka kerja bagi guru dalam mencapai maksud dan tujuan pembelajaran (AbdelWahab., 2013). Guru harus mengingat bahwa walaupun ada banyak buku pelajaran yang harus diikuti, namun, ada juga beberapa ruang untuk kontribusi pribadi mereka sebagai seorang guru (Pinter., 2009). Artinya untuk mendukung kegiatan belajar, mudah bagi guru untuk hanya mengadopsi satu atau lebih buku pelajaran English as a Foreign Language (EFL) namun, secara realistis, beberapa guru tidak dapat menemukan buku teks yang benarbenar dibutuhkan di kelas mereka (Brown, 1995). Buku teks sebagai sarana belajar yang digunakan di sekolah untuk menunjang suatu program pembelajaran (Muslich., 2010). Meskipun demikian, penggunaan buku teks dapat bermanfaat selama digunakan dengan tepat. Jadi, para guru harus dapat memilih buku teks apa yang terbaik yang dibutuhkan guru untuk peserta didik mereka.

Selain itu, buku teks memainkan peranan penting untuk mendukung implementasi kurikulum. Setelah kurikulum yang baru diterapkan oleh Departemen Pendidikan Nasional Indonesia, sejumlah penerbit kompetitif akan melibatkan para penulis profesional untuk merancang atau mengembangkan buku teks baru yang sesuai dengan kurikulum. Ada beberapa kriteria evaluasi buku teks yang diusulkan oleh para ahli seperti Cunningsworth., (1995), Harmer.,
(2007), dan Brown. (2001). Evaluasi buku teks tersebut biasanya menganalisis konten buku teks yang didasarkan pada beberapa kriteria seperti yang diusulkan oleh para ahli tersebut. Buku teks bahasa Inggris yang baik harus memenuhi kriteria penampilan fisik seperti kesesuaian desain buku teks dan kelengkapan buku teks (Cunningsworth., 1995). Selain itu, Indonesia juga memiliki Badan Standar Nasional Pendidikan (BSNP). Salah satu tugasnya adalah menganalisis buku teks dan mengevaluasi kualitas buku teks yang digunakan. Badan Standar Nasional Pendidikan memiliki beberapa kriteria untuk menilai kelayakan buku teks yang digunakan dalam proses pembelajaran. Buku teks harus memiliki semua elemen kesesuaian, yaitu: kesesuaian konten, kesesuaian presentasi, dan kesesuaian bahasa.

Buku teks harus sesuai dengan kurikulum sebagai hasil dari penerapan kurikulum dan implementasinya di sekolah (Byrd., 2001). Byrd. (2001) juga mengusulkan kriteria yang dapat digunakan dalam mengevaluasi dan memilih buku teks yang baik. Pertama, kesesuaian antara materi dan kurikulum. Kurikulum adalah pedoman proses belajar mengajar, termasuk tujuan program dan prosedur pengajaran. Oleh karena itu, kesesuaian antara materi dan kurikulum akan membantu peserta didik untuk mencapai tujuan suatu program. Kedua, kesesuaian antara materi dan proses belajar mengajar. Materi-materi tersebut harus sesuai dengan kebutuhan peserta didik, sehingga mereka dapat mempelajari materi secara efektif. Selain itu, materi dalam buku teks juga harus membantu para guru dalam mengatur proses belajar mengajar secara efektif.

Mengingat pemikiran di atas bahwa 
buku teks bahasa Inggris memainkan peran penting dalam mensukseskan implementasi kurikulum terbaru (dalam hal ini kurikulum 2013) maka hal itu membawa kita pada masalah apakah buku teks yang digunakan oleh guru telah relevan dengan materi kurikulum 2013 atau tidak. Oleh karena itu, mengacu pada semua penjelasan di atas, penelitian ini dilakukan untuk melihat buku teks bahasa Inggris yang digunakan di kelas $\mathrm{X}$ di salah satu SMA di Kuningan memenuhi kriteria evaluasi buku teks yang diajukan oleh para ahli dan Badan Standar Nasional Pendidikan, serta untuk menjelaskan relevansi buku teks bahasa Inggris dengan materi kurikulum bahasa Inggris 2013.

\section{METODE PENELITIAN}

Penelitian ini dilakukan untuk mengetahui apakah buku teks yang digunakan oleh guru telah relevan dengan materi kurikulum 2013 atau tidak. Data penelitian ini akan dikumpulkan dengan melakukan beberapa langkah. Beberapa langkah prosedural diatur secara tertib yang terdiri dari mempersiapkan penelitian, menganalisis buku teks, dan menulis laporan (Ary et al., 2002). Pertama, peneliti mempersiapkan penelitian. Sekolah yang telah menerapkan kurikulum 2013 dipilih. Setelah izin dari sekolah untuk mengumpulkan data telah diberikan, kemudian memeriksa dan menanyakan buku teks yang digunakan oleh guru untuk peserta didik di kelas X.

Kedua, peneliti menganalisis buku teks. Langkah ini diikuti oleh perancangan ceklis kriteria evaluasi buku teks yang berisi seperangkat kriteria standar untuk mengevaluasi buku teks bahasa Inggris yang akan dianalisis dari kerangka yang diusulkan oleh Cunningsworth. (1995), Harmer. (2007) dan BSNP. (2013), serta untuk menjelaskan relevansi buku teks bahasa Inggris dengan materi kurikulum bahasa Inggris 2013. Setelah buku teks didapat dan semua instrumen ceklis dibuat, menganalisis buku teks bahasa Inggris berdasarkan semua instrumen ceklis kemudian dilakukan.

Ketiga, peneliti menuliskan laporan. Setelah melakukan beberapa langkah prosedural di atas dengan tertib, langkah terakhir yaitu menuliskan laporan. Laporan ini menjelaskan setiap bagian dari penelitian dan temuan secara rinci.

\section{HASIL DAN PEMBAHASAN 3.1. Hasil}

Penelitian ini mengevaluasi buku teks bahasa Inggris berjudul Bahasa Inggris untuk SMA/MA/SMK/MAK kelas $X$ dengan menggunakan metode analisis konten. Tujuan dari penelitian ini adalah untuk mengetahui apakah buku teks bahasa Inggris berjudul Bahasa Inggris untuk SMA/MA/SMK/MAK kelas $X$ memenuhi kriteria evaluasi buku teks serta menjelaskan relevansi buku teks bahasa Inggris dengan materi kurikulum bahasa Inggris 2013.

Dalam penelitian ini, delapan kriteria digunakan untuk menjawab pertanyaan penelitian pertama "Apakah buku teks bahasa Inggris berjudul Bahasa Inggris untuk SMA/ $M A / S M K / M A K$ kelas $X$ memenuhi kriteria buku teks EFL yang baik seperti yang diusulkan oleh Cunningsworth. (1955) dan Harmer. (2007)?" Kedelapan kriteria terdiri dari (1) tujuan dan pendekatan, (2) desain dan organisasi, (3) konten bahasa, (4) skill, (5) topik, (6) metodologi, (7) pertimbangan praktis, dan (8) instruksi.

Berdasarkan data dari analisis konten, ditemukan bahwa buku teks memenuhi $66.7 \%$ dalam hal kriteria buku teks EFL yang baik seperti yang diusulkan oleh Cunningsworth. (1995) dan Harmer. (2007) dan 33.3\% dari buku teks ini tidak memenuhi kriteria buku teks EFL yang baik. Hasil analisis dijelaskan sebagai berikut.

1) Tujuan dan pendekatan

Menurut Cunningsworth. (1995), buku teks bahasa Inggris harus memenuhi dua kriteria dalam hal tujuan dan pendekatan. Pertama, konten buku teks harus sesuai dan cocok dengan silabus saat ini. Dalam buku teks ini, tidak ada kompetensi dasar 3.3 Menganalisis fungsi sosial, struktur teks, dan elemen bahasa dalam ekspresi perhatian (care), dan juga responsnya sesuai dengan konteks penggunaannya; dan tidak ada kompetensi dasar 4.4 Menyusun teks lisan 
dan teks tertulis untuk mengatakan dan menanggapi ekspresi perhatian (care) dengan memperhatikan fungsi sosial, struktur teks, dan elemen bahasa yang benar dan sesuai dengan konteksnya.

Kedua, buku teks bahasa Inggris harus menggunakan berbagai macam gaya/ cara belajar dan mengajar. BSNP. (2013) menjelaskan bahwa dalam hal pendekatan tentang bagaimana materi dalam buku teks disajikan harus memenuhi empat kriteria. Pertama, pendekatan dalam menyajikan materi harus fokus pada peserta didik. Kedua, pendekatan dalam menyajikan materi harus mengembangkan inisiatif peserta didik, pemikiran kreatif dan kritis. Ketiga, pendekatan dalam menyajikan materi harus mengembangkan kemandirian peserta didik dalam belajar. Keempat, pendekatan dalam menyajikan materi harus mengembangkan kemampuan peserta didik untuk merefleksikan diri dan mengevaluasi diri.

Buku teks ini hampir memenuhi keempat kriteria menurut BSNP. (2013) tentang bagaimana materi dalam buku teks harus disajikan. Namun, tidak ada interaksi antara peserta didik dengan lingkungan yang disebutkan dalam kriteria pertama. Mengenai kriteria pertama, pendekatan dalam menyajikan materi harus fokus pada peserta didik. Kriteria ini berkaitan dengan apakah pendekatan/gaya dalam menyajikan materi merangsang interaksi antara peserta didik, peserta didik dengan guru, dan peserta didik dengan lingkungan (BSNP., 2013). Buku teks ini tidak sesuai dengan kriteria tersebut karena pendekatan dalam menyajikan materi dalam buku teks ini hanya merangsang interaksi antar peserta didik sekitar $75 \%$ dan juga peserta didik dengan guru sekitar $25 \%$.

2) Desain dan organisasi

Bagaimana buku teks dirancang dan bagaimana buku teks disusun akan disajikan dalam desain dan organisasi dengan lima kriteria. Desain berhubungan dengan isi total buku teks. Ini juga berkaitan dengan apakah tata letaknya jelas dan mudah diikuti. Mengenai organisasi, ini berkaitan dengan organisasi buku teks dan urutan bab-babnya. Hal ini juga berkaitan dengan proses daur ulang dan revisi di dalam buku teks. Selain itu, ini berkaitan dengan kesesuaian beberapa materi untuk pembelajaran individu.

Kriteria pertama yaitu mengenai desain, hal ini berbicara tentang isi total buku teks. Isi total buku teks pelajaran mencakup: buku siswa, buku guru, buku kerja, dan kaset. Buku teks yang berjudul Bahasa Inggris untuk SMA/MA/SMK/MAK Kelas $X$ tidak sesuai dengan kriteria ini. Isi total buku teks ini tidak lengkap karena tidak ada kaset atau audio di buku teks ini. Jadi buku pelajaran ini tidak dilengkapi dengan skil mendengarkan yang baik.

Mengenai kesesuaian beberapa materi untuk pembelajaran individu dalam kriteria organisasi, ini berkaitan dengan adanya belajar mandiri atau latihan individu yang dapat dilakukan di rumah. Buku teks ini tidak mencakup materi untuk pembelajaran individu karena tidak memiliki latihan mandiri atau latihan belajar individu yang dapat dilakukan di rumah.

3) Konten bahasa

Cunningsworth (1995) mengatakan bahwa konten bahasa berkaitan dengan bagian tata bahasa (grammar) dan kosa kata dalam buku teks. Tata bahasa (grammar) berkaitan dengan tiga kriteria. Pertama, item tata bahasa (grammar) harus sesuai untuk setiap level, dengan mempertimbangkan kebutuhan peserta didik. Kedua, item tata bahasa (grammar) harus disajikan dalam unit yang cukup kecil untuk memudahkan pembelajaran. Ketiga, penerapan tata bahasa (grammar) harus seimbang antara bentuk bahasa dan penggunaan bahasa.

Mengenai kosa kata (vocabulary), ini berkaitan dengan empat kriteria. Pertama, apakah materi pembelajaran kosa kata termasuk dalam pembelajaran yang tepat. Kedua, apakah kosa kata merupakan bagian utama dari sebuah pembelajaran. Ketiga, apakah kosakata disajikan dengan cara yang terstruktur dan terarah. Keempat, apakah peserta didik peka terhadap struktur leksikon melalui latihan pembelajaran kosa kata. Mengenai kriteria kedua, apakah kosa kata merupakan bagian utama dari sebuah pembelajaran. Buku teks ini tidak memenuhi kriteria tersebut karena 
kosa kata bukan merupakan bagian utama dari sebuah pembelajaran dalam buku teks ini. Inti dari buku teks ini adalah dalam hal berbicara dan menulis.

4) Skill atau Keterlampilan

Dalam hal skill, menurut Harmer (2007), buku teks harus mencakup empat skill dan keempatnya harus diintegrasikan. Keempat skill itu adalah mendengarkan, berbicara, membaca, dan menulis. Dalam hal skill mendengarkan, dalam buku teks ini tidak memenuhi kriteria tersebut karena tidak ada bagian, materi, atau latihan yang secara eksplisit di bagian mendengarkan, tidak seperti skill lainnya. Buku teks ini gagal mengeksplorasi skill mendengarkan untuk para peserta didik. Di buku teks ini, hanya ada 3 bagian mendengarkan. Dua di antaranya, peserta didik harus membuka tautan online, dan yang lainnya adalah dalam bentuk mendengarkan apa yang akan dibaca oleh guru.

skill kedua adalah berbicara. skill berbicara berhubungan dengan dua kriteria. Pertama, apakah materinya dalam bentuk presentasi/praktik lisan, dialog, permainan peran, atau kegiatan komunikasi. Kedua, apakah ada strategi khusus untuk percakapan atau kegiatan lisan lainnya dalam materi berbicara di buku teks, misalnya berdebat, memberikan ceramah. Dan buku teks ini memenuhi dua kriteria tersebut.

skill ketiga adalah membaca. skill membaca berhubungan dengan tujuh kriteria, yaitu (1) Apakah membaca teks sering terjadi; (2) Apakah teks bacaan autentik; (3) Apakah materi bacaan membantu pemahaman dengan mengatur adegan, memberikan informasi latar belakang, atau memberikan pertanyaan pra-baca; (4) Apakah pertanyaan pemahaman bacaan mencakup pertanyaan literal, pertanyaan pemprosesan wacana, atau pertanyaan inferensi; (5) Apakah materi bacaan terkait dengan keempat skil lain; (6) Apakah subjek membaca teks sesuai (menarik, menantang, topikal, beragam, dapat diterima secara budaya, atau tidak mungkin sampai saat ini); dan (7) Apakah jenis teks, yang digunakan, sesuai.

Dari ketujuh kriteria, buku teks ini hanya memenuhi empat kriteria. Buku teks ini tidak memenuhi kriteria kedua, kriteria ketiga, dan kriteria kelima. Hampir semua teks dalam buku ini juga merupakan teks yang non-autentik. Tidak ada latihan membaca sebelumnya yang berisi tiga materi pemahaman seperti mengatur adegan, memberikan informasi latar belakang, atau memberikan pertanyaan pra-baca di buku teks ini. Dan kemudian, bahan bacaan disajikan secara terpisah dan tidak ada materi atau latihan yang terintegrasi dalam bagian ini.

skill keempat adalah menulis. Keterampilan menulis berhubungan dengan empat kriteria, yaitu (1) Apakah ada kontrol, bimbingan, bebas atau semi-tertulis dalam buku teks; (2) Apakah paragraphing diajarkan secara memadai; (3) Apakah perhatian diberikan pada sumber bahasa khusus untuk bentuk tertulis, seperti tanda baca, ejaan, tata letak; dan (4) Apakah peserta didik didorong untuk meninjau kembali dan mengedit karya tulis mereka.

Buku teks ini tidak memenuhi kriteria kedua dan ketiga. Karena tidak ada latihan yang berisi kegiatan menulis paragraphing di buku teks ini. Dan buku teks ini tidak memiliki aktivitas yang memperhatikan sumber bahasa khusus untuk bentuk tertulis. 5) Topik

Buku teks bahasa Inggris juga harus memenuhi tiga kriteria dalam hal topik (Cunningsworth., 1995). Pertama, buku teks harus memiliki variasi dan cakupan topik yang cukup. Kedua, topik tersebut harus memperluas kesadaran peserta didik dan memperkaya pengalaman mereka. Ketiga, topik tersebut harus terkait dengan konteks sosial dan budaya yang disajikan dalam buku pelajaran.

Mengenai kriteria pertama, buku teks yang berjudul Bahasa Inggris untuk SMA/MA/SMK/MAK Kelas $X$ memiliki cakupan topik yang cukup beragam karena isi buku teks ini diatur sesuai dengan topik. Mengenai kriteria kedua, topik tersebut harus memperluas kesadaran peserta didik dan memperkaya pengalaman mereka. Beberapa topik dalam buku teks ini diharapkan dapat 
memperluas kesadaran peserta didik dengan memperkenalkan masalah sosial, sensitif, sosial-budaya yang terjadi dalam kehidupan sehari-hari mereka.

Mengenai kriteria ketiga, topik tersebut harus terkait dengan konteks sosial dan budaya yang disajikan dalam buku pelajaran tersebut. Namun, hampir banyak topik yang disajikan dalam buku tersebut tidak mengandung unsur budaya Indonesia. Jadi, peserta didik tidak dapat menghubungkannya dengan budaya mereka sendiri.

6) Metodologi

Menurut Cunningsworth. (1995), buku teks bahasa Inggris harus memenuhi tiga kriteria dalam hal metodologi. Pertama, teknik yang di gunakan untuk mempresentasikan/mempraktikkan materi bahasa baru harus cocok untuk peserta didik. Kedua, kemampuan komunikatif harus dikembangkan dalam buku teks. Ketiga, materi yang termasuk dalam buku teks harus memberi saran/membantu peserta didik tentang kemampuan belajar dan strategi belajar. Buku pelajaran ini tidak memenuhi kriteria pertama. Namun sayangnya, buku teks ini juga gagal dalam hal menyajikan item baru dalam kedua teknik, yaitu secara deduktif dan induktif.

7) Pertimbangan praktis

Buku teks bahasa Inggris harus memenuhi dua kriteria dalam hal pertimbangan praktis. Pertama, seluruh biaya paket sebuah buku teks mewakili nilai uang yang baik. Kedua, buku pelajaran harus kuat dan tahan lama. Buku teks ini memenuhi kedua kriteria tersebut dalam hal pertimbangan praktis.

8) Instruksi

Menurut Harmer. (2007), buku teks bahasa Inggris harus memenuhi dua kriteria dalam hal instruksi. Pertama, instruksi harus jelas dan tidak ambigu. Kedua, instruksi harus ditulis dalam bahasa yang dapat dimengerti oleh peserta didik. Mengenai instruksi, hampir semua latihan yang ada di dalam buku teks berjudul Bahasa Inggris untuk SMA/MA/SMK/MAK Kelas $X$ sangat jelas dan mudah dimengerti. Jelas tentang tindakan apa yang harus dilakukan peserta didik dan skill apa yang dibutuhkan oleh peserta didik dalam latihan tersebut.

Selanjutnya, tujuh kriteria juga digunakan untuk menjawab pertanyaan penelitian pertama "Apakah buku teks bahasa Inggris berjudul Bahasa Inggris untuk SMA/MA/SMK/MAK kelas $X$ memenuhi kriteria buku teks EFL yang baik seperti yang ditetapkan oleh Badan Standar Nasional Pendidikan?" Kriteria tersebut terdiri dari: 1) Kesesuaian materi dengan standar kompetensi dan kompetensi dasar, 2) Akurasi materi, 3) Bahan belajar pendukung, 4) Ketepatan bahasa, 5) Teknik presentasi, 6) Teknik belajar mengajar, 7) Cakupan presentasi.

\subsection{Pembahasan}

Berdasarkan data dari analisis konten, ditemukan bahwa buku teks berjudul Bahasa Inggris untuk SMA/MA/ $S M K / M A K$ kelas $X$ dikategorikan "baik" dengan mencapai skor rata-rata $90 \%$ dari ketujuh kriteria yang ditentukan oleh Badan Standar Nasional Pendidikan. Tujuh kriteria dapat diklasifikasikan "baik" yaitu dengan perolehan dari kesesuaian materi dengan standar kompetensi dan kompetensi dasar (83.3\%), akurasi materi $(83.3 \%)$, bahan pendukung pembelajaran (90\%), ketepatan bahasa $(100 \%)$, teknik presentasi $(100 \%)$, teknik belajar mengajar (100\%), dan cakupan presentasi $(81.8 \%)$. Analisis disajikan sebagai berikut.

Analisis menunjukkan bahwa buku Bahasa Inggris untuk SMA/MA/SMK/MAK kelas $X$ memenuhi sebagian besar kriteria evaluasi buku teks yang ditentukan oleh Badan Standar Nasional Pendidikan. Buku Bahasa Inggris untuk SMA/MA/SMK/MAK kelas $X$ memenuhi sebagian besar kriteria dalam sub-aspek relevansi materi terhadap kurikulum, keakuratan materi, bahan belajar pendukung, ketepatan bahasa, teknik presentasi, teknik belajar mengajar, dan cakupan presentasi. Namun, ada beberapa item dalam ceklis yang tidak terpenuhi.

Dalam aspek konten dan aspek akurasi materi misalnya, buku teks ini tidak memenuhi dalam hal teks interpersonal karena tidak memberikan kesempatan 
yang cukup bagi para peserta didik untuk berkomunikasi secara interpersonal. Buku Bahasa Inggris untuk SMA/MA/SMK/MAK kelas $X$ tidak memiliki kegiatan berbicara (speaking) yang memungkinkan peserta didik untuk melakukan komunikasi secara interpersonal yang disertai dengan penjelasan tentang struktur, fitur linguistik, dan ciri-ciri teks interpersonal.

Dalam aspek bahan pendukung pembelajaran, buku Bahasa Inggris untuk SMA/MA/SMK/MAK kelas $X$ tidak mengarahkan peserta didik untuk memiliki skil, sikap, dan keterampilan yang dibutuhkan untuk melakukan suatu pekerjaan tertentu. Padahal keterampilan kejuruan memiliki peran yang sangat penting dalam era pembangunan saat ini untuk memenuhi tuntutan kompetensi kerja. Memberikan layanan bimbingan karir di sekolah oleh para guru diharapkan agar peserta didik memiliki keterampilan dalam mengambil keputusan karirnya di masa depan, dan juga dapat memberikan berbagai informasi terkait dunia kerja sesuai dengan bidang keahlian para peserta didik. Jadi, buku teks ini tidak memfasilitasi peserta didik untuk mengembangkan kemampuan kejuruan mereka yang merupakan skil, keterampilan, dan sikap untuk melakukan suatu pekerjaan tertentu.

Dalam aspek presentasi, buku Bahasa Inggris untuk SMA/MA/SMK/MAK kelas $X$ kurang dalam bidang cakupan presentasi karena tidak memberikan ringkasan dan indeks penulis. Buku teks bahasa Inggris berjudul Bahasa Inggris untuk SMA/MA/ $S M K / M A K$ Kelas $X$ tidak memberikan ringkasan kepada peserta didik pada akhir setiap bab yang menyajikan poin utama dari setiap pelajaran yang diajarkan. Buku teks ini juga tidak memiliki indeks penulis. Indeks penulis adalah daftar penulis yang karyanya digunakan dalam materi yang ada di dalam buku dan diikuti oleh nomor halaman di mana nama mereka muncul di buku teks tersebut.

Dalam aspek ketepatan bahasa, teknik presentasi, dan teknik belajar mengajar, buku Bahasa Inggris untuk SMA/MA/SMK/MAK Kelas $X$ sudah relevan dengan kurikulum 2013, karena buku teks ini memenuhi semua kriteria dalam aspek tersebut.
Untuk menjawab pertanyaan penelitian kedua "Bagaimana materi-materi dalam buku teks relevan dengan materi kurikulum bahasa Inggris 2013?" Penelitian ini menemukan bahwa buku teks bahasa Inggris yang digunakan relatif relevan dengan kurikulum 2013 dengan sedikit kurangnya relevansi dengan kurikulum 2013. Oleh karena itu, diharapkan bahwa guru dapat mengatasi beberapa kekurangan tersebut dengan materi lain untuk mencapai tujuan yang ditargetkan dalam kurikulum 2013.

\section{KESIMPULAN}

Penelitian ini dilakukan untuk mengevaluasi konten buku teks bahasa Inggris untuk SMA kelas $\mathrm{X}$, buku teks bahasa Inggris resmi yang diterbitkan oleh pemerintah, yang telah ditulis berdasarkan kurikulum 2013, memenuhi kriteria evaluasi buku teks dan untuk mengevaluasi buku teks yang relevan dengan materi kurikulum bahasa Inggris 2013 itu sendiri.

Ditemukan bahwa buku teks yang dianalisis memenuhi $66.7 \%$ dalam hal kriteria buku teks EFL yang baik seperti yang diusulkan oleh Cunningsworth dan Harmer. Kriterianya berisi delapan kriteria evaluasi buku teks, yaitu (1) tujuan dan pendekatan, (2) desain dan organisasi, (3) konten bahasa, (4) skill, (5) topik, (6) metodologi, (7) pertimbangan praktis, dan (8) instruksi. Kemudian, 33.3\% dari buku teks ini tidak memenuhi kriteria buku teks EFL yang baik.

Ada beberapa kelemahan yang ditemukan dalam buku teks ini. Pertama, tidak ada kompetensi dasar 3.3 dan kompetensi dasar 4.4, dan juga, tidak ada interaksi antara peserta didik dengan lingkungan dalam hal tujuan dan pendekatan. Kedua, tidak ada buku kerja dan kaset. Buku pelajaran ini juga tidak memiliki latihan belajar mandiri atau belajar individu yang dapat dilakukan di rumah. Ketiga, dalam hal konten bahasa, kosa kata tidak merupakan bagian utama dari sebuah pembelajaran dalam buku teks ini.

Keempat, tidak ada materi mendengarkan dalam skill mendengarkan. Hampir semua teks dalam buku ini juga merupakan teks yang non-autentik. Tidak 
ada latihan pra-baca yang berisi tiga materi pemahaman; mengatur adegan, memberikan informasi latar belakang, atau memberikan pertanyaan pra-baca di buku teks ini. Dan kemudian, bahan bacaan disajikan secara terpisah dan tidak ada materi atau latihan yang terintegrasi dalam bagian ini. Tidak ada latihan yang berisi kegiatan menulis paragraphing. Kemudian, buku teks ini tidak memiliki aktivitas yang memberikan perhatian pada sumber bahasa khusus untuk bentuk tertulis. Kelima, hampir semua topik yang ditampilkan dalam teks tidak mengandung budaya Indonesia. Yang terakhir, dalam hal metodologi, buku teks ini gagal dalam hal penyajian item baru dalam kedua teknik, yaitu deduktif dan induktif.

Selain itu, berdasarkan hasil dan analisis penelitian yang telah dilakukan, peneliti juga dapat menyimpulkan bahwa buku teks bahasa Inggris berjudul Bahasa Inggris untuk SMA/MA/SMK/MAK kelas $X$ dikategorikan "baik" dengan mencapai skor rata-rata $90 \%$ dari ketujuh kriteria yang ditetapkan oleh Badan Standar Nasional Pendidikan. Tujuh kriteria dapat diklasifikasikan "baik" yaitu dengan perolehan dari kesesuaian materi dengan standar kompetensi dan kompetensi dasar (83.3\%), akurasi materi (83.3\%), bahan pendukung pembelajaran (90\%), ketepatan bahasa $(100 \%)$, teknik presentasi $(100 \%)$, teknik belajar mengajar (100\%), dan cakupan presentasi $(81.8 \%)$.

Dan juga buku teks bahasa Inggris yang digunakan relatif relevan dengan kurikulum 2013 dengan sedikit kurangnya relevansi dengan kurikulum 2013. Oleh karena itu, diharapkan bahwa guru dapat menyelesaikan beberapa kekurangan tersebut dengan materi lain untuk mencapai tujuan yang ditargetkan dalam kurikulum 2013. Misalnya, mengenai ketiadaan materi mendengarkan, guru dapat menyediakan materi mendengarkan dengan mencari sumber yang relevan dari sumber lain.

\section{DAFTAR RUJUKAN}

Abdel Wahab, M. M. (2013). Developing an English language textbook evaluative checklist. IOSR Journal of Research \& Method in Education, 1 (3), 55-70.

Altbach, P. G., Kelly, G. P., Petrie, H. G., \& Weis, L. (1991). Textbooks in American Society Politics, Policy, and Pedagogy. New York: State University Press.

Ary, D., Jacobs, L. C., \& Razavieh, A. (2002). Introduction to research (6th ed). Belmont: Wadsworth.

Brown, H. D. (2001). Teaching by principle: An interactive approach to language pedagogy. New York: Pearson Education.

Brown, J. D. (1995). The elements of language curriculum: A systematic approach to program development. Boston: Heinle \& Heinle.

BSNP. (2013). Instrumen Penilaian Tahap 1 Buku Teks Pelajaran Bahasa Inggris Untuk Siswa Sekolah Menengah Atas/Madrasah Aliyah. Jakarta: Departemen Pendidikan Nasional.

Byrd, P. (2001). Textbooks: Evaluation for selection and analysis for implementation. In M. Celce-Murcia (Ed.) Teaching English as a second or a foreign language (3rd Ed). Boston: Heinle \& Heinle Publishers.

Cunningsworth, A. (1995). Choosing Your Coursebook. Macmilan: Heinemann.

Garinger, D. (2001). Textbook selection for the ESL classroom. Eric Digest.

Harmer, J. (2007). How to teach English. England: Pearson Education Limited.

Lee, Y. (2003). A package for an English paragraph: An evaluation of the course-book used in two EFL writing courses. English Teaching, 58 (3), 165-188.

Muslich, Masnur. (2010). Texy Book Writing (Dasar-Dasar Pemahaman Penulisan dan Pemakaian Buku Teks). Jogjakarta: Ar-Ruzz Media.

Pinter, A. (2009). Teaching young learners. Oxford: Oxford University Press.

Richards, J. C. (2001). Curriculum development in language teaching. Cambridge: Cambridge University Press.

Tomlinson, B. (2001). Materials development. In R. Carter \& D. Nunan (Eds.), Teaching English to speakers of other languages. Cambridge: Cambridge University Press. 